\title{
FAKTOR PENENTU PARTISIPASI SEKOLAH ANAK PADA RUMAH TANGGA SEKTOR PERTANIAN DI INDONESIA
}

\author{
(DETERMINANT FACTORS OF CHILDREN SCHOOL PARTICIPATION \\ IN AGRICULTURAL HOUSEHOLDS IN INDONESIA)
}

\author{
Diyang Gita Cendikia \\ Badan Pusat Statistik Provinsi Kalimantan Selatan
}

Korespondensi penulis: diyang.dgc@bps.go.id

\begin{abstract}
The opportunity of demographic dividend is the biggest motivation in improving the quality of the population. As one of the components of the population quality, education is also a long-term investment. Economic activities in Indonesia depends on the agricultural sector. This study aims to determine the determinants of children's school participation in agricultural households. Using the 2018 National Social and Economic Survey data, the results of binary logistic regression analysis show that economic activity has the most significant contribution to determine children's school participation in agricultural households. Children in agricultural households who are not involved in economic activities tend to attend school. Other important factors in determining children's school participation in agricultural households are government assistance, the age of household heads (KRT), education of KRT, employment status of KRT, number of household members, residence area, and socio-economic status. Increasing the determinants of school participation is expected to help the population adapt to the technology-based modern agricultural sector and achieve prosperity in agricultural households.
\end{abstract}

Keywords: the agricultural sector, schooling investment, binary logistic regression, education, human capital

\begin{abstract}
Abstrak
Peluang dalam memanfaatkan bonus demografi menjadi motivasi terbesar dalam meningkatkan kualitas penduduk. Sebagai salah satu komponen yang menentukan kualitas penduduk, pendidikan juga merupakan bentuk investasi jangka panjang. Karena kegiatan ekonomi di Indonesia bergantung pada sektor pertanian, maka penelitian ini bertujuan untuk mengetahui faktor penentu partisipasi sekolah anak pada rumah tangga sektor pertanian. Dengan menggunakan data Survei Sosial dan Ekonomi Nasional Tahun 2018, hasil analisis regresi logistik biner menunjukkan bahwa kegiatan ekonomi yang dilakukan anak memiliki kontribusi yang paling besar dalam memengaruhi partisipasi sekolah anak pada rumah tangga sektor pertanian. Anak pada rumah tangga pertanian yang tidak terlibat dalam kegiatan ekonomi rumah tangga cenderung masih bersekolah. Faktor penting lain dalam penentu partisipasi sekolah anak dalam rumah tangga sektor pertanian adalah bantuan pemerintah, umur kepala rumah tangga (KRT), pendidikan KRT, status pekerjaan KRT, jumlah anggota rumah tangga, daerah tempat tinggal, dan status sosial ekonomi. Dengan meningkatkan faktor penentu partisipasi sekolah, diharapkan mampu mempermudah penduduk dalam beradaptasi dengan sektor pertanian modern yang berbasis teknologi serta mencapai kesejahteraan pada rumah tangga sektor pertanian.
\end{abstract}

Kata Kunci: sektor pertanian, investasi bersekolah, regresi logistik biner, pendidikan, modal manusia 


\section{PENDAHULUAN}

Kemajuan teknologi di zaman industri 4.0 memberikan tantangan bagi negara-negara di dunia, termasuk Indonesia sebagai negara dengan jumlah penduduk yang besar (Ghufron, 2018). Peluang dalam memanfaatkan bonus demografi, kondisi yang ditandai dengan jumlah penduduk usia produktif yang lebih banyak dibandingkan jumlah penduduk non produktif, dapat menjadi motivasi terbesar dalam memperbaiki kualitas penduduk (Pranadji, Sumaryanto, \& Gunawan, 2013). Perbaikan pada kualitas penduduk seringkali dinilai sebagai salah satu isu utama dalam ketenagakerjaan (Soleh, 2017; Tjiptoherijanto, 2017; Pranadji, Sumaryanto, \& Gunawan, 2013).

Kualitas penduduk merupakan salah satu komponen yang tidak mudah diukur. Salah satu pengukuran yang sering digunakan adalah melalui Indeks Pembangunan Manusia (IPM) (BPS, 2019b). United Nations Development Programme (UNDP) (2019) menunjukkan bahwa pada tahun 2018 Indonesia termasuk dalam kelompok negara dengan IPM menengah atau tepatnya berada di peringkat ke-111 dari 189 negara. Kualitas penduduk dapat ditingkatkan melalui peningkatan komponen pendidikan sehingga mampu beradaptasi dengan kemajuan teknologi sebagai jalan mencapai kesejahteraan (BPS, 2019b).

Pendidikan sering disebut sebagai investasi karena memiliki manfaat yang dirasakan dalam jangka panjang (Atmanti, 2005). Dalam perspektif ekonomi, pendidikan merupakan bentuk investasi sumber daya manusia yang akan memberikan keuntungan pada masa depan, baik untuk pribadi, masyarakat, maupun negara. Pilihan seseorang untuk bersekolah atau berpartisipasi sekolah akan menentukan siklus kehidupan pada masa depan (Priyono, 2015).

Beberapa penelitian telah menitikberatkan perhatiannya dalam mengkaji determinan partisipasi sekolah di Indonesia secara umum (Ngadi, 2016; Perdana, 2015; Budiani, 2014; Takahashi, 2011). Akan tetapi, penelitian mengenai partisipasi sekolah yang berfokus pada anak dalam rumah tangga sektor pertanian di Indonesia cukup terbatas. Padahal, kegiatan ekonomi Indonesia masih bergantung pada sektor pertanian. Sektor ini menyerap sebagian besar tenaga kerja di
Indonesia dan memberikan kontribusi terbesar ke-3 dalam Produk Domestik Bruto (PDB) pada tahun 2018 (BPS, 2019a). Oleh karena itu, tulisan ini akan mengkaji faktor penentu partisipasi sekolah pada anak dalam rumah tangga sektor pertanian. Selanjutnya, tulisan ini diharapkan dapat memberikan masukan sebagai bahan untuk merancang strategi pembangunan berkelanjutan yang dapat meningkatkan pertumbuhan ekonomi secara umum serta meningkatkan produktivitas kerja dan kesejahteraan rumah tangga sektor pertanian secara khusus pada masa depan.

\section{METODE PENELITIAN}

Data yang digunakan dalam tulisan ini adalah data Survei Sosial Ekonomi Nasional Tahun 2018 (Susenas 2018). Survei ini dilakukan oleh Badan Pusat Statistik (BPS) setiap enam bulan sekali (yaitu bulan Maret dan September). Tulisan in menggunakan data hasil pencacahan Susenas 2018 bulan Maret. Data Susenas 2018 digunakan karena ketersediaan variabel sosial ekonomi yang cukup lengkap dibandingkan dengan data dari hasil survei lain di Indonesia, seperti Survei Pertanian Antar Sensus (Sutas) dan Survei Angkatan Kerja Nasional (Sakernas). Variabel yang tidak terdapat pada Sutas tetapi ada pada Susenas 2018 adalah variabel partisipasi sekolah, bantuan pemerintah, dan pengeluaran rumah tangga yang digunakan dalam tulisan ini. Selain itu, pemilihan penggunaan data Susenas 2018 pada bulan Maret karena jumlah sampel Susenas 2018 pada bulan ini (300.000 rumah tangga) lebih banyak dibandingkan dengan sampel Susenas pada bulan September (75.000 rumah tangga). Dengan menggunakan jumlah sampel yang lebih banyak, maka analisis yang dihasilkan lebih mampu menggambarkan keadaan populasi.

Dalam pencacahannya, Susenas bulan Maret tahun 2018 menggunakan dua jenis kuesioner, yaitu Kuesioner VSEN18K dan VSEN18KP. Kuesioner VSEN18K merupakan kuesioner yang berisi informasi pokok rumah tangga, seperti pendidikan, kesehatan, pekerjaan, perumahan, dan pengeluaran rumah tangga. Sedangkan kuesioner VSEN18KP merupakan kuesioner yang berisi keterangan konsumsi/ pengeluaran makanan dan bukan makanan serta pendapatan/penerimaan rumah tangga (BPS, 2018). 
Dengan demikian, variabel yang digunakan dalam tulisan ini merujuk pada ketersediaan data pada kedua kuesioner tersebut.

Jumlah sampel dalam Susenas 2018 bulan Maret adalah sebanyak 300.000 rumah tangga di 34 Provinsi di Indonesia. Adapun metode pengumpulan data Susenas 2018 adalah wawancara dengan menggunakan kuesioner pada semua rumah tangga yang terpilih sebagai sampel. Namun demikian, tidak semua individu dalam sampel rumah tangga terpilih dijadikan unit analisis dalam tulisan ini. Unit analisis yang digunakan adalah anak dengan kepala rumah tangga yang memiliki pekerjaan utama pada sektor pertanian, sehingga diperoleh sampel rumah tangga sebanyak 98.320 anak. Definisi anak dalam penelitian ini adalah penduduk yang berumur 7-17 tahun yang mengacu pada UndangUndang Nomor 20 Tahun 2003 tentang Sistem Pendidikan Nasional serta Undang-Undang Nomor 23 Tahun 2002 tentang Perlindungan Anak ${ }^{1}$. Selain itu, cakupan sektor pertanian dalam penelitian ini meliputi enam subsektor sesuai dengan klasifikasi BPS, yaitu: subsektor tanaman padi dan palawija, hortikultura, perkebunan, perikanan, peternakan, dan kehutanan.

Variabel terikat dalam penelitian ini adalah partisipasi sekolah yang dinotasikan dengan PARTS. Variabel tersebut terdapat pada kuesioner VSEN18K rincian 612. Definisi operasional partisipasi sekolah dalam penelitian ini mengacu pada konsep dan definisi dalam Susenas 2018, yaitu berkaitan dengan aktivitas pendidikan baik formal maupun nonformal yang diperoleh anak. Dalam penelitian ini, variabel partisipasi sekolah dikategorikan menjadi dua, yaitu (1) tidak/belum pernah sekolah atau tidak bersekolah lagi, dan (2) masih bersekolah.

Variabel bebas yang digunakan dalam penelitian ini terdiri dari bantuan pemerintah, jenis kelamin kepala rumah tangga (KRT), umur KRT, pendidikan KRT, status kerja KRT, jumlah anggota rumah tangga, daerah tempat tinggal, status sosial ekonomi, kegiatan ekonomi

1 Dalam Undang-Undang Nomor 20 Tahun 2003 Pasal 6 Ayat 1 disebutkan bahwa setiap warga negara yang berusia 7-15 tahun wajib mengikuti pendidikan dasar anak, dan jenis kelamin anak. Adapun definisi operasional variabel bebas mengacu pada konsep dan definisi dalam Susenas 2018 dan dapat dilihat secara rinci pada Tabel 1.

Metode analisis tulisan ini menggunakan metode analisis deskriptif dan metode analisis inferensial. Analisis deskriptif digunakan untuk melihat gambaran partisipasi sekolah anak pada rumah tangga sektor pertanian. Metode analisis deskriptif yang digunakan berupa tabulasi silang partisipasi sekolah berdasarkan karakteristik rumah tangga dan karakteristik individu. Sedangkan metode analisis inferensial yang digunakan berupa analisis regresi logistik biner untuk mengetahui faktor penentu partisipasi pendidikan rumah tangga sektor pertanian. Dengan demikian, model umum yang terbentuk adalah sebagai berikut.

$$
\begin{aligned}
\text { PARTS }= & \beta_{0}+\beta_{1} \text { BANTUAN }+\beta_{2} \text { JKKRT }+\beta_{3} \\
& \text { UMURKRT }+\beta_{4} \text { DIDIKKRT }+\beta_{5} \\
& \text { JNKERJA }+\beta_{6} \text { JART }+\beta_{7} \text { DTT }+\beta_{8} \text { SSE } \\
& +\beta_{9} \text { JKA }+\beta_{10} \text { KE }+\varepsilon \quad \ldots .(1)
\end{aligned}
$$

Hipotesis yang dibangun dalam tulisan ini adalah:

1. Anak yang tinggal dalam rumah tangga yang mendapatkan bantuan dari pemerintah diduga cenderung masih bersekolah (berpartisipasi sekolah) dibandingkan dengan anak yang tinggal dalam rumah tangga yang tidak mendapatkan bantuan dari pemerintah.

2. Anak yang tinggal dalam rumah tangga dengan KRT yang berjenis kelamin laki-laki diduga cenderung masih bersekolah (berpartisipasi sekolah) dibandingkan dengan anak yang tinggal dalam rumah tangga dengan KRT yang berjenis kelamin perempuan.

3. Semakin bertambah umur KRT, anak yang tinggal dalam rumah tangga sektor pertanian diduga semakin cenderung masih bersekolah (berpartisipasi sekolah).

(SD/sederajat dan SMP/sederajat). Sementara itu, dalam Undang-Undang Nomor 23 Tahun 2002 disebutkan bahwa anak adalah seseorang yang belum berusia 18 tahun. 
Jurnal Kependudukan Indonesia | Vol. 15, No. 2, Desember 2020 | 215-226

Tabel 1. Definisi Operasional Variabel Bebas

\begin{tabular}{|c|c|c|c|}
\hline Variabel & Notasi & Definisi Operasional & Kategori/Numerik \\
\hline (1) & $(2)$ & (3) & (4) \\
\hline \multicolumn{4}{|c|}{ Karakteristik Rumah Tangga } \\
\hline $\begin{array}{l}\text { Bantuan } \\
\text { pemerintah }\end{array}$ & BANTUAN & $\begin{array}{l}\text { Anak dikategorikan mendapat bantuan pemerintah adalah } \\
\text { jika anak dalam rumah tangga sektor pertanian memiliki } \\
\text { Kartu Indonesia Pintar (KIP) dan/atau memperoleh } \\
\text { Program Indonesia Pintar (PIP) yang terdapat pada } \\
\text { kuesioner VSEN18K rincian } 616 \text { dan rincian } 617 \text {. }\end{array}$ & $\begin{array}{l}\text { Kategori } \\
\text { 1. Mendapatkan bantuan } \\
\text { 0. Tidak mendapatkan } \\
\text { bantuan }\end{array}$ \\
\hline $\begin{array}{l}\text { Jenis kelamin } \\
\text { KRT }\end{array}$ & JKKRT & $\begin{array}{l}\text { Jenis Kelamin yang terdapat pada kuesioner VSEN18K } \\
\text { rincian } 405 \text {. }\end{array}$ & $\begin{array}{l}\text { Kategori } \\
\text { 1. Laki-laki } \\
\text { 0. Perempuan }\end{array}$ \\
\hline
\end{tabular}

\begin{tabular}{lll}
\hline \multirow{2}{*}{ Umur KRT } & UMURKRT & $\begin{array}{l}\text { Umur berdasarkan ulang tahun terakhir saat survei. } \\
\text { Variabel umur terdapat pada kuesioner VSEN18K rincian } \\
407 .\end{array}$ \\
\hline & $\begin{array}{l}\text { Pendidikan KRT dilihat berdasarkan ijazah pendidikan } \\
\text { tertinggi yang ditamatkan KRT. Variabel tersebut terdapat } \\
\text { pada kuesioner VSEN18K rincian 615. }\end{array}$
\end{tabular}

Numerik

Pendidikan KRT

DIDIKKRT
Kategori
2. Tamat SMP sederajat
1. Minimal tamat SMA sederajat
0. Maksimal tamat SD

\begin{tabular}{|c|c|c|}
\hline Status kerja KRT & JNKERJA & $\begin{array}{l}\text { Status pekerjaan mengacu pada status/kedudukan dalam } \\
\text { pekerjaan utama yang terdapat pada kuesioner VSEN18K } \\
\text { rincian } 805 \text {. KRT dikategorikan bekerja pada sektor } \\
\text { informal jika memiliki status/kedudukan berusaha sendiri, } \\
\text { berusaha dibantu buruh tidak tetap, pekerja bebas, atau } \\
\text { pekerja keluarga/tidak dibayar. Sedangkan KRT } \\
\text { dikategorikan bekerja pada sektor formal jika memiliki } \\
\text { status/kedudukan dalam pekerjaan utama sebagai } \\
\text { berusaha dibantu buruh } \\
\text { buruh/karyawan/pegawai. }\end{array}$ \\
\hline $\begin{array}{l}\text { Daerah tempat } \\
\text { Tinggal }\end{array}$ & DTT & $\begin{array}{l}\text { Klasifikasi daerah tempat tinggal responden yang dapat } \\
\text { dilihat pada kuesioner VSEN18K rincian } 104 \text {. }\end{array}$ \\
\hline $\begin{array}{l}\text { Status sosial } \\
\text { ekonomi }\end{array}$ & SSE & $\begin{array}{l}\text { Pengeluaran per kapita rumah tangga terdapat pada } \\
\text { kuesioner VSEN18KP. Pengeluaran per kapita rumah } \\
\text { tangga dibagi menjadi } 5 \text { kelompok kuintil. Anak yang } \\
\text { berada pada rumah tangga dengan pengeluaran per kapita } \\
\text { pada kelompok } 20 \% \text { terbawah dikategorikan sebagai anak } \\
\text { dengan SSE kuintil 1. Begitu juga dengan anak yang } \\
\text { berada pada rumah tangga dengan pengeluaran perkapita } \\
\text { pada kelompok } 20 \% \text { teratas dikategorikan sebagai anak } \\
\text { dengan SSE kuintil } 1 \text {. }\end{array}$ \\
\hline
\end{tabular}
Kategori
1. Formal
0. Informal

Kategori
1. Kota
0. Desa

Kategori

1. Kuintil 2

2. Kuintil 3

3. Kuintil 4

4. Kuintil 5

0. Kuintil 1

\section{Karakteristik Anak}

\begin{tabular}{|c|c|c|c|}
\hline Kegiatan ekonomi & $\mathrm{KE}$ & $\begin{array}{l}\text { Kegiatan ekonomi yang dilakukan anak selama seminggu } \\
\text { terakhir yang terlihat pada kuesioner VSEN18K rincian } \\
801 \text {. }\end{array}$ & $\begin{array}{l}\text { Kategori } \\
\text { 1. Bekerja } \\
\text { 0. Tidak Bekerja }\end{array}$ \\
\hline $\begin{array}{l}\text { Jenis kelamin } \\
\text { anak }\end{array}$ & JKA & $\begin{array}{l}\text { Jenis kelamin anak yang terlihat pada kuesioner } \\
\text { VSEN18K rincian } 405 \text {. }\end{array}$ & $\begin{array}{l}\text { Kategori } \\
\text { 1. Laki-Laki } \\
\text { 0. Perempuan }\end{array}$ \\
\hline
\end{tabular}


4. Anak yang tinggal dalam rumah tangga dengan KRT yang berpendidikan tinggi diduga cenderung masih bersekolah (berpartisipasi sekolah) dibandingkan dengan anak yang tinggal dalam rumah tangga dengan KRT yang berpendidikan rendah.

5. Anak yang tinggal dalam rumah tangga dengan KRT yang bekerja pada sektor formal diduga cenderung masih bersekolah (berpartisipasi sekolah) dibandingkan dengan anak yang tinggal dalam rumah tangga yang bekerja pada sektor informal.

6. Anak yang tinggal dalam rumah tangga di perkotaan diduga cenderung masih bersekolah (berpartisipasi sekolah) dibandingkan dengan anak yang tinggal dalam rumah tangga di perdesaan.

7. Semakin banyak anggota rumah tangga diduga semakin kurang cenderung anak masih bersekolah (berpartisipasi sekolah).

8. Semakin status sosial ekonomi rumah tangga diduga semakin cenderung anak masih bersekolah (berpartisipasi sekolah).

9. Anak yang bekerja diduga kurang cenderung masih bersekolah (berpartisipasi sekolah) dibandingkan dengan anak yang tidak bekerja.

10. Anak laki-laki diduga cenderung masih bersekolah (berpartisipasi sekolah) dibandingkan dengan anak perempuan.

\section{HASIL DAN PEMBAHASAN}

Salah satu dasar pembangunan yang berkelanjutan adalah pembangunan yang berbasis penduduk atau yang lebih sering dikenal dengan subjek dan objek pembangunan. Selain itu, dari sisi ekonomi penduduk memiliki peran penting yang dilihat sebagai konsumen dan/atau sebagai produsen. Sebagai konsumen, penduduk Indonesia memiliki andil dalam menciptakan pangsa pasar yang besar dan menarik investor. Berperan sebagai produsen, penduduk mampu menghasilkan luaran yang besar melalui besarnya jumlah tenaga kerja yang dimiliki. Peranan penduduk sebagai produsen dan konsumen tersebut lebih mudah saat dilihat dari kuantitasnya, yang seringkali menjadi tolok ukur dan penentu pembangunan.

Jumlah penduduk yang besar cenderung memiliki kualitas yang relatif rendah dan dianggap sebagai beban pembangunan. Namun, permasalahan kuantitas tersebut dapat diatasi dengan meningkatkan kualitas (Ananta, 1986). Bukan hanya kuantitas, kualitas juga menjadi sorotan dalam pembangunan, terlebih pada era industri 4.0. yang ditandai dengan kemampuan menyesuaikan diri dan bersaing dalam kemajuan teknologi. Dengan demikian, jumlah penduduk yang besar dengan kualitas yang baik diharapkan mampu menjadi modal untuk mencapai kesejahteraan nasional.

Peningkatan kualitas penduduk melalui investasi pendidikan dibedakan menjadi dua jenis, yaitu private investment dan public investment. Jenis investasi yang dibahas dalam tulisan ini adalah private investment berupa investasi pendidikan pada tingkat individu dalam rumah tangga sektor pertanian yang didefinisikan melalui variabel partisipasi sekolah.

Kondisi pada rumah tangga sektor pertanian di Indonesia berdasarkan Susenas 2018 menunjukkan bahwa 92,4 persen anak usia 7-17 tahun berpartisipasi sekolah atau memiliki status masih bersekolah. Hal tersebut mengindikasikan bahwa rumah tangga sektor pertanian telah melakukan investasi pada pendidikan. Secara rinci, gambaran karakteristik unit analisis dalam penelitian ini dapat dilihat pada Tabel 2.

Karakteristik rumah tangga dan individu memiliki peranan penting dalam pendidikan anak (Tansel, 2002). Oleh karena itu, secara umum karakteristik unit analisis dilihat melalui karakteristik rumah tangga dan karakteristik anak. Jika dilihat berdasarkan karakteristik rumah tangga, sebagian besar anak yang masih bersekolah berada pada rumah tangga sektor pertanian yang tidak mendapatkan bantuan pemerintah, memiliki KRT dengan jenis kelamin laki-laki, berpendidikan maksimal SD, serta tinggal di desa. Sedangkan jika dilihat berdasarkan karakteristik anak, sebagian besar anak yang masih sekolah adalah anak yang tidak bekerja dan memiliki jenis kelamin laki-laki. 
Jurnal Kependudukan Indonesia | Vol. 15, No. 2, Desember 2020|215-226

Tabel 2. Distribusi Karakteristik Unit Analisis pada Rumah Tangga Sektor Pertanian menurut Partisipasi Sekolah

\begin{tabular}{|c|c|c|c|}
\hline Variabel & Kategori & $\begin{array}{l}\text { Tidak/Belum Sekolah/ } \\
\text { Tidak Bersekolah Lagi }\end{array}$ & Masih Bersekolah \\
\hline (1) & $(2)$ & (3) & (4) \\
\hline \multicolumn{4}{|c|}{ Karakteristik Rumah Tangga } \\
\hline \multirow{3}{*}{ Bantuan pemerintah } & Mendapatkan bantuan & 8,3 & 34,0 \\
\hline & $\begin{array}{l}\text { Tidak mendapatkan } \\
\text { bantuan }\end{array}$ & 91,7 & 66,0 \\
\hline & Total & 100,0 & 100,0 \\
\hline \multirow{3}{*}{ Jenis kelamin KRT } & Laki-laki & 90,7 & 93,0 \\
\hline & Perempuan & 9,3 & 7,0 \\
\hline & Total & $\mathbf{1 0 0 , 0}$ & $\mathbf{1 0 0 , 0}$ \\
\hline \multirow{4}{*}{ Pendidikan KRT } & Tamat SMP sederajat & 8,4 & 16,1 \\
\hline & $\begin{array}{l}\text { Minimal tamat SMA } \\
\text { sederajat }\end{array}$ & 7,1 & 17,8 \\
\hline & Maksimal tamat SD & 84,5 & 66,1 \\
\hline & Total & $\mathbf{1 0 0 , 0}$ & $\mathbf{1 0 0 , 0}$ \\
\hline \multirow{3}{*}{ Status kerja KRT } & Formal & 12,5 & 16,7 \\
\hline & Informal & 87,5 & 83,3 \\
\hline & Total & 100,0 & 100,0 \\
\hline \multirow{3}{*}{ Daerah tempat tinggal } & Kota & 9,2 & 13,6 \\
\hline & Desa & 90,8 & 86,4 \\
\hline & Total & 100,0 & 100,0 \\
\hline \multirow{6}{*}{ Status sosial ekonomi } & Kuintil 2 & 20,6 & 20,0 \\
\hline & Kuintil 3 & 16,6 & 20,3 \\
\hline & Kuintil 4 & 17,1 & 20,2 \\
\hline & Kuintil 5 & 18,1 & 20,1 \\
\hline & Kuintil 1 & 27,6 & 19,4 \\
\hline & Total & 100,0 & 100,0 \\
\hline \multicolumn{4}{|c|}{ Karakteristik Anak } \\
\hline \multirow{3}{*}{ Kegiatan ekonomi } & Bekerja & 38,6 & 3,7 \\
\hline & Tidak Bekerja & 61,4 & 96,3 \\
\hline & Total & 100,0 & 100,0 \\
\hline \multirow{3}{*}{ Jenis kelamin anak } & Laki-Laki & 58,9 & 52,0 \\
\hline & Perempuan & 41,1 & 48,0 \\
\hline & Total & 100,0 & 100,0 \\
\hline
\end{tabular}

Sumber: Susenas 2018 (diolah)

Pendidikan akan menunjang pengetahuan, keterampilan, dan keahlian tenaga kerja sebagai modal untuk penghasilannya pada masa datang (Becker, 1962). Dalam konteks investasi, seseorang membuat keputusan untuk bersekolah (atau melanjutkan sekolah) atau tidak bersekolah akan mempertimbangkan dua hal, yaitu: (1) nilai manfaat yang bisa diperoleh kalau bersekolah, dan (2) biaya yang harus ditanggung untuk menempuh pendidikan tersebut (Priyono, 1998). Hasil analisis regresi logistik biner untuk mengetahui faktor penentu partisipasi sekolah pada rumah tangga sektor pertanian dapat dilihat pada Tabel 3 .

Chernichovsky (1985) berpendapat bahwa perubahan kondisi demografis dan sosial ekonomi rumah tangga menentukan partisipasi sekolah pada anak. Dengan demikian, variabel independen yang digunakan dalam penelitian ini merupakan variabel turunan dari kondisi demografis dan sosial ekonomi. Tabel 3 menunjukkan bahwa berdasarkan karakteristik rumah tangga, bantuan pemerintah, umur KRT, pendidikan KRT, status pekerjaan KRT, jumlah anggota rumah tangga, daerah tempat tinggal, dan status sosial ekonomi memengaruhi partisipasi sekolah anak pada rumah tangga sektor pertanian ( $P$-value 0,05$)$. Hasil penelitian ini sejalan dengan penelitian yang dilakukan oleh Ngadi (2016) dan Perdana (2015) yang menyebutkan bahwa partisipasi sekolah anak pada rumah tangga perkebunan dipengaruhi oleh lingkungan (termasuk karakteristik rumah tangga). 
Tabel 3. Nilai Signifikansi, Odds Ratio, dan Nilai Wald Hasil Analisis Regresi Logistik Biner

\begin{tabular}{|c|c|c|c|c|}
\hline \multicolumn{2}{|c|}{ Variabel } & Signifikansi & EXP (B) & Wald \\
\hline & (1) & (2) & (3) & (4) \\
\hline \multirow{2}{*}{ Bantuan pemerintah } & Mendapatkan bantuan & $0,000 * * *$ & 6,022 & $1.640,492$ \\
\hline & \multicolumn{2}{|c|}{ Tidak mendapatkan bantuan (Referensi) } & & \\
\hline \multirow{2}{*}{ Jenis kelamin KRT } & Laki-laki & 0,901 & 1,006 & 0,016 \\
\hline & \multicolumn{2}{|l|}{ Perempuan (Referensi) } & & \\
\hline \multicolumn{2}{|l|}{ Umur KRT } & $0,000 * * *$ & 1,007 & 28,398 \\
\hline \multirow[b]{2}{*}{ Pendidikan KRT } & Tamat SMP sederajat & $0,000 * * *$ & 2,419 & 364,381 \\
\hline & $\begin{array}{l}\text { Minimal tamat SMA Sederajat } \\
\text { Maksimal tamat SD (Referensi) }\end{array}$ & $0,000 * * *$ & 3,145 & 543,968 \\
\hline \multirow{2}{*}{ Status kerja KRT } & Formal & $0,031 * *$ & 1,091 & 4,649 \\
\hline & Informal (Referensi) & & & \\
\hline \multicolumn{2}{|c|}{ Jumlah anggota rumah tangga } & $0,025 * *$ & 0,984 & 5,025 \\
\hline \multirow[t]{2}{*}{ Daerah tempat tinggal } & Kota & $0,001 * * *$ & 1,167 & 11,707 \\
\hline & Desa (Referensi) & & & \\
\hline \multirow{5}{*}{ Status sosial ekonomi } & Kuintil 2 & $0,000 * * *$ & 1,364 & 60,389 \\
\hline & Kuintil 3 & $0,000^{* * *}$ & 1,699 & 154,707 \\
\hline & Kuintil 4 & $0,000 * * *$ & 1,656 & 137,223 \\
\hline & Kuintil 5 & $0,000 * * *$ & 1,607 & 115,866 \\
\hline & Kuintil 1 (Referensi) & & & \\
\hline \multirow{2}{*}{ Kegiatan ekonomi } & Bekerja & $0,000 * * *$ & 0,068 & $7.145,173$ \\
\hline & Tidak bekerja (Referensi) & & & \\
\hline \multirow[t]{2}{*}{ Jenis kelamin anak } & Laki-Laki & 0,149 & 0,961 & 2,084 \\
\hline & Perempuan (Referensi) & & & \\
\hline
\end{tabular}

**) $P$-value $<0,05 ; * * *) P$-value $<0,01$

Sumber: Susenas 2018 (diolah)

Konsumsi rumah tangga dibiayai dari tiga komponen yaitu labor income (pendapatan dari bekerja), transfer, dan asset based reallocation. Transfer sendiri dapat dibedakan menjadi dua, yaitu private transfer dan public transfer (Lee \& Masson, 2011). Bantuan pemerintah yang merupakan bagian dari private transfer digunakan dalam analisis tulisan ini karena bantuan tersebut dianggap memiliki peran yang cukup penting dalam mengkaji partisipasi sekolah anak, khususnya anak pada rumah tangga sektor pertanian.

Hasil analisis logit menunjukkan terdapat perbedaan partisipasi sekolah anak berdasarkan jenis bantuan pemerintah yang diterima. Anak yang tinggal pada rumah tangga yang mendapatkan minimal salah satu bantuan pemerintah cenderung 6,02 kali masih bersekolah dibandingkan dengan anak yang tidak mendapatkan bantuan pemerintah. Hal ini sejalan dengan temuan Khanam (2005) di Bangladesh yang menunjukkan bahwa tingginya partisipasi pendidikan anak dipengaruhi oleh adanya program bantuan berupa subsidi pendidikan perempuan yang dilakukan pemerintah. Studi Martorell dkk., (2016) di Amerika Serikat juga menunjukkan bahwa pemberian insentif finansial pada orang tua dan anak mampu meningkatkan partisipasi sekolah.

Selain kepemilikan bantuan pemerintah, variabel lain dari karakteristik rumah tangga adalah variabel demografi KRT. Umur merupakan salah satu variabel demografi sebagai indikator dalam menentukan kedewasaan seseorang sehingga mampu menimbang baik dan buruk, termasuk dalam hal menentukan partisipasi sekolah anak yang tinggal dalam rumah tangganya. Khanam (2005) menemukan bahwa umur orang tua tidak menentukan partisipasi sekolah anak di Bangladesh, berbeda dengan hasil analisis yang menunjukkan bahwa umur KRT berpengaruh pada partisipasi sekolah anak. Setiap penambahan satu tahun umur KRT, maka anak cenderung 1,01 kali untuk masih bersekolah..

Variabel demografi KRT selanjutnya adalah pendidikan KRT. Pendidikan anak tidak terlepas dari peran orang tua. Beberapa penelitian telah menyebutkan bahwa pendidikan orang tua memiliki peran penting dan memengaruhi partisipasi anak secara tidak langsung (Perdana, 2015; Khanam, 2005; 
Jayachandran, 2002; Ermisch \& Francesconi, 2001). Bahkan, pendidikan KRT merupakan salah satu faktor sosial ekonomi terpenting (Todaro \& Smith, 2015).

Terdapat perbedaan partisipasi sekolah anak berdasarkan pendidikan KRT. Anak dengan KRT yang memiliki pendidikan tamat SMP/sederajat cenderung 2,42 kali masih bersekolah dibandingkan anak dengan KRT maksimal tamat SD. Selain itu, anak dengan KRT yang memiliki pendidikan minimal tamat SMA sederajat cenderung 3,15 kali masih bersekolah dibandingkan anak dengan KRT maksimal tamat SD. Hasil penelitian ini sejalan dengan penelitian yang dilakukan oleh Iddrisu dkk., (2017), Abafita dan Kim (2015), serta Perdana (2015) yang menyatakan bahwa orang tua dengan pendidikan tinggi lebih mengerti pentingnya pendidikan. Orang tua akan mendorong anak untuk mendapatkan pendidikan yang setara bahkan melebihi orang tuanya. Chernichovsky (1985) menyebutkan bahwa yang didorong orang tua tidak hanya dalam hal partisipasi sekolah, tetapi juga dalam hal lama sekolah. Orang tua yang berpendidikan lebih tinggi akan menyekolahkan anaknya lebih lama dibandingkan dengan orang tua yang berpendidikan lebih rendah.

Variabel lain dari KRT sebagai faktor penentu partisipasi pendidikan anak adalah status pekerjaan. Kesenjangan pendapatan antara pekerja sektor formal dan informal berasal dari rendahnya pendidikan dan keterampilan yang dimiliki. Temuan dalam penelitian ini menunjukkan bahwa terdapat perbedaan partisipasi sekolah anak berdasarkan status pekerjaan KRT. Anak dengan KRT yang bekerja di sektor formal lebih cenderung 1,09 kali masih bersekolah dibandingkan dengan anak dengan KRT yang bekerja di sektor informal. Temuan ini sejalan dengan hasil penelitian yang dilakukan oleh Tansel (2002) mengenai variabel penentu capaian pendidikan pada anak-anak di Turki yang menunjukkan bahwa status pekerjaan merupakan salah satu variabel dari faktor individu dan rumah tangga yang menentukan capaian pendidikan. Ayah dengan status pekerjaan berusaha sendiri cenderung memiliki capaian pendidikan yang relatif rendah. Hal tersebut menyiratkan bahwa peluang bekerja dalam rumah tangga (khususnya pada sektor pertanian) menjadi alternatif agar anak dapat terus bersekolah. Begitu juga dengan penelitian Khanam (2005) mengenai partisipasi dan pencapaian pendidikan anak di Bangladesh, yang menyebutkan bahwa anak dengan ayah status pekerjaan yang tidak tetap cenderung untuk mengombinasi bekerja dan sekolah atau cenderung bekerja penuh waktu.

Jumlah anggota rumah tangga menentukan seberapa besar kebutuhan yang harus dipenuhi. Sebagian studi menemukan bahwa jumlah anggota rumah tangga memiliki korelasi negatif dengan partisipasi sekolah (Perdana, 2015; Rolleston, 2009; Jayachandran, 2002). Namun demikian, sebagian lagi menemukan bahwa data yang digunakan dalam penelitiannya tidak dapat menunjukkan perbedaan partisipasi sekolah jika dilihat berdasarkan jumlah anggota rumah tangga (Chernichovsky, 1985).

Hasil analisis dalam tulisan ini menunjukkan bahwa terdapat perbedaan partisipasi sekolah anak berdasarkan jumlah anggota rumah tangga. Anak cenderung 0,98 kali kurang berpartisipasi sekolah pada setiap penambahan satu anggota rumah tangga. Dengan kata lain, semakin banyak jumlah anggota rumah tangga, semakin kecil kecenderungan anak memiliki status masih bersekolah. Hal ini sejalan dengan penelitian yang dilakukan oleh Perdana (2015) yang menunjukkan bahwa semakin banyak anggota rumah tangga, semakin banyak beban yang ditanggung, sehingga semakin kecil kemampuan rumah tangga dalam membelanjakan pendapatan untuk pendidikan. Selain itu, semakin sedikit jumlah anggota rumah tangga yang berada dalam kelompok usia kerja akan memperbesar peluang anak untuk tidak berpartisipasi dalam bersekolah serta melakukan kegiatan ekonomi untuk membantu menghasilkan pendapatan atau melakukan kegiatan rumah tangga (Rolleston, 2009).

Kewilayahan memiliki keterikatan dengan tingkat kesejahteraan suatu daerah (Rolleston, 2009). Tempat tinggal seseorang menentukan akses orang tersebut untuk memperbaiki kualitas hidup, termasuk dalam pendidikan. Kesenjangan antarwilayah menimbulkan kesenjangan partisipasi pendidikan antarwilayah. Temuan dalam penelitian ini menunjukkan bahwa terdapat perbedaan partisipasi sekolah anak berdasarkan daerah tempat tinggal. Anak yang tinggal di daerah perkotaan cenderung 1,17 kali masih bersekolah dibandingkan dengan anak yang tinggal di 
daerah perdesaan. Kondisi tersebut mengindikasikan bahwa penduduk di perkotaan memiliki kesempatan yang lebih besar dibandingkan dengan penduduk perdesaan. Hasil penelitian ini sejalan dengan hasil penelitian yang dikemukakan oleh Perdana (2015) bahwa anak yang tinggal di perkotaan memiliki akses pendidikan yang relatif lebih mudah.

Status sosial ekonomi seringkali digunakan sebagai indikator kesejahteraan yang menentukan perilaku seseorang, termasuk perilaku dalam pengambilan keputusan untuk bersekolah. Selain itu, status sosial ekonomi rumah tangga juga dapat menggambarkan aset yang dimiliki sebuah rumah tangga. Dalam hubungannya dengan partisipasi sekolah, status sosial ekonomi bersifat sebagai price effect. Jika rumah tangga tersebut memiliki barang pengganti/aset yang dapat menggantikan peran dan tugas anak, maka anak memiliki kebebasan untuk berpartisipasi sekolah (Chernichovsky, 1985).

Status sosial ekonomi dalam tulisan ini juga berpengaruh terhadap partisipasi sekolah anak. Anak yang tinggal dalam rumah tangga pada kuintil 2 cenderung 1,36 kali masih bersekolah dibandingkan dengan anak yang tinggal dalam rumah tangga pada kuintil 1. Begitu juga dengan anak yang tinggal dalam rumah tangga pada kuintil 3 cenderung 1,70 kali masih bersekolah dibandingkan dengan anak yang tinggal dalam rumah tangga pada kuintil 1 . Selanjutnya, anak yang tinggal dalam rumah tangga pada kuintil 4 cenderung 1,66 kali masih bersekolah dibandingkan dengan anak yang tinggal dalam rumah tangga pada kuintil 1. Selain itu, anak yang tinggal dalam rumah tangga pada kuintil 5 cenderung 1,61 kali masih bersekolah dibandingkan dengan anak yang tinggal dalam rumah tangga pada kuintil 1 . Temuan ini sejalan dengan penelitian yang dilakukan sebelumnya oleh Perdana (2015), Takahashi (2011), dan Jayachandran (2002) yang menyebutkan bahwa anak yang berada dalam rumah tangga dengan tingkat kesejahteraan yang tinggi cenderung untuk masih bersekolah dibandingkan dengan anak yang tinggal dalam rumah tangga dengan tingkat kesejahteraan yang rendah. Kemiskinan dapat menyebabkan anak dari rumah tangga miskin memiliki kesempatan yang kecil untuk bersekolah. Dengan demikian, semakin baik kesejahteraan rumah tangga, semakin mudah rumah tangga tersebut untuk memberikan akses pendidikan pada anak-anak mereka.

Berdasarkan teori alokasi waktu yang dikemukakan Becker (1965), rumah tangga diasumsikan akan memaksimumkan utilitasnya dengan meminimalisasi biaya untuk memproduksi luaran. Pada beberapa negara berkembang, anak seringkali memberikan kontribusi ekonomi dalam rumah tangga (Khanam, 2005). Berkaitan dengan nilai seorang anak, kadang kala anak diperkenankan melakukan kegiatan ekonomi seperti bekerja untuk membantu menghasilkan pendapatan, bahkan bekerja untuk menunjang kehidupan rumah tangga. Terlebih pada rumah tangga sektor pertanian, rumah tangga cenderung untuk meminimalkan biaya yang dikeluarkan (misalkan: upah pekerja) dengan mempekerjakan anak. Beberapa penelitian sebelumnya telah menunjukkan bahwa masuknya anak dalam pasar kerja menentukan partisipasi sekolah anak (Rolleston, 2019; Khanam, 2005).

Hasil penelitian menunjukkan bahwa terdapat perbedaan partisipasi sekolah pada anak jika dilihat berdasarkan kegiatan ekonomi anak. Anak yang bekerja cenderung 0,07 kali kurang masih bersekolah dibandingkan dengan anak yang tidak bekerja. Sejalan dengan penelitian yang dilakukan oleh Ngadi (2016) serta Putnick dan Bornstein (2015) yang menyebutkan bahwa kegiatan ekonomi anak memiliki korelasi negatif dengan partisipasi sekolah. Secara rinci, hasil penelitian yang dilakukan oleh Parikh dan Sadoulet (2005) juga menunjukkan bahwa anak mengalokasikan waktu lebih banyak dalam bekerja sebagai respons dari rendahnya tingkat kesejahteraan rumah tangga yang kemudian akan berdampak pada anak cenderung kurang untuk berpartisipasi sekolah.

Partisipasi sekolah anak juga dipengaruhi oleh persepsi orang tua dan anak. Gayatri (2008) mengatakan bahwa hal ini dipengaruhi oleh karakteristik yang melekat pada diri orang tua (pendidikan) dan anak (jenis kelamin). Persepsi negatif orang tua terhadap pendidikan perempuan akan berdampak pada ketimpangan gender dalam pendidikan. Corcoran dan Jennings (2018) dalam penelitiannya juga menunjukkan bahwa terdapat perbedaan partisipasi sekolah pada anak perempuan dan laki-laki. Anak laki- 
laki lebih cenderung untuk bersekolah dibandingkan dengan anak perempuan. Bertolak belakang dengan hasil analisis pada tulisan ini, jika dilihat berdasarkan jenis kelamin anak atau jenis kelamin KRT, secara statistik data menunjukkan bahwa tidak terdapat perbedaan partisipasi sekolah anak pada rumah tangga sektor pertanian. Salah satu dugaan mengenai temuan ini adalah gap ketidaksetaraan gender di Indonesia yang semakin menyempit jika dilihat dari Indeks Pembangunan Gender yang mengalami peningkatan (BPS, 2019c).

\section{KESIMPULAN DAN SARAN}

Persentase anak yang masih bersekolah berdasarkan data Susenas 2018 relatif besar, yaitu sebesar 92,4\%. Secara umum, sebagian besar anak pada rumah tangga sektor pertanian di Indonesia memiliki karakteristik tidak mendapatkan bantuan pemerintah $(68 \%)$, berjenis kelamin laki-laki (52,5\%), tinggal di perdesaan (86,8\%), memiliki KRT dengan pendidikan maksimal tamat SD $(67,5 \%)$, memiliki KRT dengan jenis kelamin laki-laki $(92,9 \%)$, serta memiliki KRT yang bekerja di sektor informal $(83,6 \%)$.

Partisipasi sekolah anak pada rumah tangga sektor pertanian di Indonesia ditentukan oleh karakteristik rumah tangga dan karakteristik anak, yaitu bantuan pemerintah, umur KRT, pendidikan KRT, status pekerjaan KRT, jumlah anggota rumah tangga, daerah tempat tinggal, status sosial ekonomi, dan kegiatan ekonomi yang dilakukan anak. Tiga faktor penentu yang berkontribusi besar dalam partisipasi sekolah anak pada rumah tangga sektor pertanian adalah kegiatan ekonomi anak, bantuan pemerintah, dan pendidikan KRT.

Keterbatasan dalam tulisan ini meliputi penggunaan variabel yang hanya tersedia pada pada Susenas 2018 . Padahal, ada variabel lain yang juga dapat menjadi faktor penentu partisipasi sekolah anak, seperti urutan kelahiran anak, akses bersekolah (contoh: jarak, biaya dan alat transportasi yang digunakan), serta luas lahan pertanian. Adapun saran yang diberikan berdasarkan hasil penelitian ini adalah sebagai berikut.

Mengacu pada variabel kegiatan ekonomi yang memberikan kontribusi terbesar sebagai faktor penentu partisipasi sekolah anak, pemerintah dapat membatasi kegiatan ekonomi yang dilakukan oleh anak sehingga anak dapat fokus untuk mendapatkan pendidikan. Hal ini dapat dilakukan melalui penjaringan anak di tempat umum (termasuk lahan pertanian) pada jam sekolah. Selain itu, alternatif lain yang dapat dilakukan pemerintah adalah mencanangkan tambahan pembelajaran secara daring melalui situs web, stasiun televisi nasional, atau siaran radio agar anak yang terpaksa bekerja tetap mendapatkan akses pembelajaran. Pembelajaran tersebut dapat mengenai pembelajaran yang sesuai dengan kurikulum, pembelajaran terkait sektor pertanian, dan motivasi agar anak tidak putus sekolah.

Terkait dengan bantuan pemerintah yang meningkatkan peluang anak rumah tangga sektor pertanian untuk bersekolah, pemerintah dapat melanjutkan bantuan atau program subsidi pendidikan. Selain itu, evaluasi mengenai penerima, penggunaan bantuan, kualitas, dan mekanisme program yang diberikan juga perlu dikaji secara berkala dan dapat diakses secara bebas.

Mengacu pada variabel pendidikan KRT, pemerintah dapat memberikan sosialisasi secara rutin pada KRT mengenai investasi pendidikan anak. Selain itu, pemerintah dapat lebih gencar melakukan sosialisasi berbagai program dalam membatasi kelahiran sehingga kualitas anak (pendidikan dan kesehatan) dapat lebih diutamakan.

Terkait penelitian selanjutnya, peneliti dapat menambah beberapa variabel lain yang dianggap penting untuk dianalisis, seperti urutan kelahiran anak, akses bersekolah (contoh: jarak, biaya dan alat transportasi yang digunakan), serta luas lahan pertanian.

\section{DAFTAR PUSTAKA}

Abafita, J., \& Kim, C. S. (2015). Determinants of childrens schooling: The case of Tigray Region, Ethiopia. Educational Research and Reviews, 10(8), 1130-1146. https://doi.org/0.5897/ERR2015.2095 
Ananta, A. (1986). Mutu Modal Manusia: Suatu Pemikiran mengenai Kualitas Penduduk. Jakarta: Lembaga Demografi Fakultas Ekonomi Universitas Indonesia.

Atmanti, H.D. (2005). Investasi sumber daya manusia melalui pendidikan. Jurnal Dinamika Pembangunan, 2(1), 30-39.

Badan Pusat Statistik [BPS].(2018). Pedoman pencacahan survei sosial ekonomi nasional. Badan Pusat Statistik. https://sirusa.bps.go.id/webadmin/pedoman/20 18_1558_ped_Pedoman\%20Petugas\%20Penc acah\%20Susenas\%20.pdf

(2019a). Statistik Indonesia Tahun 2019. Badan Pusat Statistik. https://www.bps.go.id/publication/2019/07/04/ daac1ba18cae1e90706ee58a/statistikindonesia-2019.html

. (2019b). Indeks Pembangunan Manusia

2018. Badan Pusat Statistik. https://www.bps.go.id/publication/2019/08/27/ 34432798c6ae95c6751bfbba/indekspembangunan-manusia-2018.html

(2019c). Data dinamis pada https://bps.go.id/site/resultTab

Becker, G.S. (1962). Investment in human capital: A theoretical analysis. Journal of political economy, 70(5, Part 2), 9-49.

Becker, G.S. (1965), "A theory of the allocation of time”, Economic Journal, Vol. 75, 493-517.

Budiani, S. (2014). Determinan Anak Putus Sekolah di Sulawesi (Analisis Data Susenas 2012) [Tesis Magister, Universitas Indonesia]. http://lib.ui.ac.id/detail?id=20389396\&lokasi= lokal

Chernichovsky, D. (1985). Socioeconomic and demographic aspects of school enrollment and attendance in rural Botswana. Economic development and cultural change, 33(2), 319332. https://www.jstor.org/stable/1153230

Corcoran, S. P., \& Jennings, J. (2018). The gender gap in charter school enrollment. Educational Policy, 32(5), 635-663. https://doi.org/10.1177/0895904816673737
Ermisch, J., \& Francesconi, M. (2001). Family matters: Impacts of family background on educational attainments. Economica, 68(270), 137-156. https://doi.org/10.1111/1468-0335.00239

Gayatri, F. (2008). Faktor dan Dampak Ketimpangan Pendidikan Perempuan dalam Kehidupan Perempuan (Kasus: Kecamatan Cariu, Kabupaten Bogor, Jawa Barat) [Skripsi. Institut Pertanian Bogor]. https://repository.ipb.ac.id/handle/123456789/ $\underline{1874}$

Ghufron, G. (2018). Revolusi industri 4.0: tantangan, peluang, dan solusi bagi dunia pendidikan. Prosiding Seminar Nasional dan Diskusi Panel Multidisiplin Ilmu I(1). http://www.proceeding.unindra.ac.id/index.ph p/dispanas2018/article/viewFile/73/45

Iddrisu, A. M., Danquah, M., \& Quartey, P. (2017). Analysis of School Enrollment in Ghana: A Sequential Approach. Review of Development Economics, 21(4), 1158-1177. https://doi.org/10.1111/rode.12302

Jayachandran, U. (2002). Socio-economic determinants of school attendance in India. Working papers 103, Centre for Development Economics, Delhi School of Economics. http://www.cdedse.org/pdf/work103.pdf

Khanam, R. (2005, March). Impact of child labour on school attendance and school attainment: Evidence from Bangladesh. In Population Association of America Annual Meeting (PAA 2005) (pp. 1-40). University of Southern Queensland. http://paa2005.princeton.edu/

Lee, R., \& Mason, A., (2011). Population aging and the generational economy. A Global Perspective. Edward Elgar Publishing, Northampton, Massachusetts.

Martorell, P., Miller, T., Santibañez, L., \& Augustine, C. H. (2016). Can incentives for parents and students change educational inputs? Experimental evidence from summer school. Economics of Education Review, 50, 113-126. https://doi.org/10.1016/j.econedurev.2015.12. 003

Ngadi. (2016). The school enrollment of children in the plantation sector in Indonesia. Jurnal 
Jurnal Kependudukan Indonesia | Vol. 15, No. 2, Desember 2020 | 215-226

Kependudukan Indonesia, 11(2), 93-102. https://doi.org/10.14203/jki.v11i2.49

Parikh, A., \& Sadoulet, E. (2005). The effect of parents' occupation on child labor and school attendance in Brazil . CUDARE Working Paper. University of California Berkeley https://are.berkeley.edu/ esadoulet/papers/Chi ldLabor.pdf

Perdana, N. S. (2015). Faktor-faktor yang berpengaruh terhadap aksesibilitas memperoleh pendidikan untuk anak-anak di Indonesia. Jurnal Pendidikan dan Kebudayaan, 21(3), 279-298. https://doi.org/10.24832/jpnk.v21i3.191

Pranadji, T., Sumaryanto, \& Gunawan, E. (2013). Penduduk, pertanian, ketenagakerjaan, dan bahaya pengangguran dalam pembangunan. analisis kebijakan pertanian, 11(2), 89-106. http://dx.doi.org/10.21082/akp.v11n2.2013.89 $\underline{-106}$

Priyono, E. (1998). Permintaan terhadap pendidikan: Analisis Fungsi Probabilita Bersekolah Menurut Strata Pendapatan [Tesis Magister, Universitas Indonesia]. http://lib.ui.ac.id/file?file=pdf/abstrak$\underline{77270 . p d f}$

Putnick, D. L., \& Bornstein, M. H. (2015). Is child labor a barrier to school enrollment in low-and middle-income countries? International journal of educational development, 41, 112120.

https://doi.org/10.1016/j.ijedudev.2015.02.001

Rolleston, C. (2009). Human Capital, Poverty, Educational Access and Exclusion: The Case of Ghana 1991-2006. CREATE Pathways to Access. Research Monograph No. 22. Online Submission.
Soleh, A. (2017). Masalah ketenagakerjaan dan pengangguran di Indonesia. Jurnal Ilmiah Cano Ekonomos, 6(2), 83-92. https://ejournal.upp.ac.id/index.php/Cano/article/view/ $\underline{1360}$

Takahashi, K. (2011). Determinants of Indonesian rural secondary school enrolment: gender, neighbourhood and school characteristics. Bulletin of Indonesian Economic Studies, 47(3), 395-413. https://doi.org/10.1080/00074918.2011.61905 $\underline{3}$

Tansel, A. (2002). Determinants of school attainment of boys and girls in Turkey: individual, household and community factors. Economics of education review, 21(5), 455-470. https://doi.org/10.1016/S0272$\underline{7757(01) 00028-0}$

Tjiptoherijanto, P. (2017). Dinamika Kependudukan Dan Ketenagakerjaan Indonesia. Jurnal Analis Kebijakan, I(2). http://jak.lan.go.id/index.php/jurnalpusaka/arti cle/view/67

Todaro, M.P., \& Smith, S.C. (2015). Economic Development (12 ${ }^{\text {th }}$ Edition). London: Pearson Education, Inc.

United Nations Development Programe [UNDP]. (2019). Human development report 2018. UNDP. http://www.hdr.undp.org/sites/default/files/hdr 2019.pdf 